\title{
Influence of vegetable oils addition on the selected physical properties of apple-sodium alginate edible films
}

\author{
Justyna Kadzińska ${ }^{1}$ Joanna Bryś ${ }^{1}$ - Ewa Ostrowska-Ligęza ${ }^{2}$ - Manon Estéve ${ }^{3}$. \\ Monika Janowicz ${ }^{1}$ D
}

Received: 2 March 2019 / Revised: 5 April 2019 / Accepted: 8 April 2019 / Published online: 13 April 2019

(c) The Author(s) 2019

\begin{abstract}
Edible films with fruit and vegetable purees have a potential to serve as healthy snacks, edible oven bags as well as wraps for sushi or instead of pancakes, tortillas or lavash in a gluten-free diet. The film-forming solution was prepared by mixing sodium alginate, apple puree and three kinds of vegetable oils such as rapeseed oil, coconut oil and hazelnut oil. Glycerol was used as a plasticizer. Pure sodium alginate and sodium alginate-apple films were used as control samples. All the films had the thickness and moisture content characteristic for this type of materials. The results showed that the addition of apple puree and vegetable oils had a significant effect on the visual appearance of edible films. DSC curves proved stability of the researched edible films. The drying conditions used for film production and the formulations appeared to be suitable to avoid phase separation.
\end{abstract}

Keywords Edible films · Apple puree $\cdot$ Thermal properties · Vegetable oils
Abbreviations
SA Pure sodium alginate edible film
AP Sodium alginate-apple puree edible film
RO Sodium alginate-apple puree edible film with rapeseed oil
CO Sodium alginate-apple puree edible film with coconut oil
HO Sodium alginate-apple puree edible film with hazelnut oil

Monika Janowicz

monika_janowicz@sggw.pl

1 Department of Food Engineering and Process Management, Faculty of Food Sciences, Warsaw University of Life Sciences-SGGW (WULS-SGGW), 159c Nowoursynowska St., 02-776 Warsaw, Poland

2 Division of Organic and Food Chemistry, Department of Chemistry, Faculty of Food Sciences, Warsaw University of Life Sciences-SGGW (WULS-SGGW), 159c Nowoursynowska St., 02-776 Warsaw, Poland

3 IUT Département Génie Biologique, Option Industries Alimentaires et Biologiques, Bld du Dr Petitjean, BP 17867, 21078 Dijon Cedex, France 


\section{Introduction}

Poland and France are two prominent producers of apples in the European Union with the production of approximately 3.2 million $t$ (tonnes) and 1.4 million $t$, respectively (data from 2017) [1]. In addition to its flavour properties, apples are considered beneficial for human health. They possess numerous nutritional and bioactive components, including dietary fibre, sugars, acids and vitamins, e.g. vitamin $\mathrm{C}$ (approx. $8 \mathrm{mg}$ per fruit) that is essential for supporting immune system and forming collagen. Apples are also rich in phenolic compounds which contribute to their antioxidant capacity and may help prevent cancer and cardiovascular disease [2-5].

Edible films are defined as a thin material based on biopolymers [6]. They are independent structures formed separately, and then applied to the food product on its surface, between its layers or can even be sealed in edible pouches [7]. There are many trends in the technology of edible films which are strongly dependent on their further application, including antimicrobial compounds incorporation for fresh fruit [8], minimally processed vegetables [9] or meat [10], nanocompounds incorporation and cross-linking to improve mechanical and water vapour barrier properties of biopolymer films. The effect of this type of modification is to increase their potential to replace the conventional non-biodegradable petroleum-based plastics, especially in the food packaging industries [11-14] as well as probiotic [15], minerals and vitamins [16] incorporation for medical applications. Another promising direction in the research on edible films is an addition of fruit and vegetable purees or flours into film-forming solutions. There are a lot of advantages of such materials. Sothornvit and Pitak [17] indicated that the overproduction of some cultivars is a cause of a reduction in producers' value, and they emphasized the need for searching alternative ways of processing some raw materials. What is more, they also drew attention to the fact that when fruit and vegetables are used in the form of puree or flour, there is no need to isolate the film-forming compounds, thus reducing the cost of biopolymer films production and making material preparation easier. Last but not least, in recent years there is an increasing consumers' awareness regarding the active and healthy lifestyle, which have resulted in bio-snacks such as fruit chips [5] or fresh cut vegetables [18]. Edible films with fruit and vegetable purees have also a potential to serve as healthy snacks due to their attractive colours and flavours as well as nutritional value [19]. However, they may be also used as edible oven bags [7] as well as wraps for sushi instead of seaweed or instead of pancakes, tortillas or lavash in a gluten-free diet [20].

Nonetheless, the application of edible films for various food products is still very limited due to their low water vapour barrier properties, which are caused by their hydrophilicity. Therefore, lipids are often incorporated to enhance the film water barrier properties. Unfortunately, the thermodynamic incompatibility between such compounds of composite films as proteins or polysaccharides and lipids translates to film brittleness and phase separation [21, 22]. To overcome this problem, some authors proposed the use of natural blends of proteins, 
polysaccharides and lipids directly obtained from agricultural sources such as banana flour [23], pinhão seeds [24], rice [25] or achira rhizomes [26] to take advantage of each component in the original system. Fruit and vegetable purees and flours seem to be a new opportunity for composite materials in the area of edible films [21].

In this study, sodium alginate-apple puree edible films incorporated with vegetable oils such as rapeseed oil, coconut oil and hazelnut oil were developed. Basic physical properties of the obtained films, including thickness, water content and optical properties such as colour and opacity, were determined. Thermal stability of the films was evaluated with the use of differential scanning calorimetry (DSC) and modulated differential scanning calorimetry (MDSC). The possibility to close oil droplets in the polymer matrix based on sodium alginate and apple puree was assessed by scanning electron microscopy. The photographic documentation of the film-forming solutions and the final films were also recorded.

\section{Materials and methods}

\section{Film preparation}

The sodium alginate was purchased from Sigma-Aldrich (St Louis, MO, USA). Anhydrous glycerol was obtained from POCH S.A. (Gliwice, Poland). Apples (var. Champion) and vegetable oils such as coconut oil (Limpol Sp. z o.o., Kraków, Poland), rapeseed oil (Mosso Kewpie Poland Sp. z o.o., Raszyn, Poland) and hazelnut oil (Monini, Spoleto, Italy) were purchased in a local shop.

The apples were washed, peeled and cored. The pieces were soaked in a solution of $2 \%$ citric acid for 20 min to prevent enzymatic browning. Apples were then steam blanched for $10 \mathrm{~min}$ and blended for $3 \mathrm{~min}$ in a food processor Thermomix TM31 (Vorwerk, Wuppertal, Germany) to prepare apple puree. The sodium alginate was dissolved in distilled water at $80{ }^{\circ} \mathrm{C}$ at the concentration of $1.5 \%(\mathrm{w} / \mathrm{v})$. The solutions were blended with a hand blender (Bosch, Stuttgart, Germany). Subsequently, the solutions were heated on a magnetic plate at $80{ }^{\circ} \mathrm{C}$ for 30 min under $400 \mathrm{rpm}$ constant stirring (RTC basic IKAMAG, IKA, Staufen, Germany). Then, they were cooled down to $50{ }^{\circ} \mathrm{C}$, and glycerol was added as a plasticizer to each test solution at constant glycerol/hydrocolloid ratio of $1: 2(\mathrm{v} / \mathrm{w})$. The process of plasticization was conducted at $50{ }^{\circ} \mathrm{C}$ for 20 min under $400 \mathrm{rpm}$ constant stirring (RTC basic IKAMAG, IKA, Staufen, Germany). Thereafter, the solutions were cooled down to the ambient temperature, and apple puree and vegetable oils were added at $40 \%(\mathrm{w} / \mathrm{v})$ and $2 \%(\mathrm{v} / \mathrm{v})$, respectively. Then, the solutions were blended with a hand blender (Bosch, Stuttgart, Germany) for $5 \mathrm{~min}$. The abbreviations for the different samples and their compositions are listed in Table 1. Air bubbles were removed from all film-forming solutions via vacuum degassing (vacuum dryer SPT 200, ZEAMiL Horyzont, Kraków, Poland) at $20 \mathrm{kPa}$. The film-forming solution without and with the addition of apple puree and oil was poured onto Teflon plates to create the film so that the dry matter content in the obtained structure was constant and amounted to $0.03 \mathrm{~g}$ per $\mathrm{cm}^{2}$ of the resulting film surface. For all the tested samples, 
Table 1 Abbreviations and corresponding sample compositions

\begin{tabular}{|c|c|c|c|c|c|c|}
\hline \multirow{2}{*}{$\begin{array}{l}\text { Abbre- } \\
\text { viations }\end{array}$} & \multicolumn{6}{|l|}{ Film composition } \\
\hline & $\begin{array}{l}\text { Sodium alginate } \\
\text { (\% w/v solution) }\end{array}$ & $\begin{array}{l}\text { Glycerol (\% } \\
\text { v/w hydrocol- } \\
\text { loid) }\end{array}$ & $\begin{array}{l}\text { Apple puree (\% } \\
\text { w/v solution) }\end{array}$ & $\begin{array}{l}\text { Rapeseed } \\
\text { oil (\% v/v } \\
\text { solution) }\end{array}$ & $\begin{array}{l}\text { Coconut } \\
\text { oil (\% v/v } \\
\text { solution) }\end{array}$ & $\begin{array}{l}\text { Hazelnut oil } \\
(\% \mathrm{v} / \mathrm{v} \text { solu- } \\
\text { tion) }\end{array}$ \\
\hline SA & 1.5 & 50 & 40 & 0 & 0 & 0 \\
\hline AP & & & & 0 & 0 & 0 \\
\hline RO & & & & 2 & 0 & 0 \\
\hline $\mathrm{CO}$ & & & & 0 & 2 & 0 \\
\hline $\mathrm{HO}$ & & & & 0 & 0 & 2 \\
\hline
\end{tabular}

two-stage drying process was applied. First, the film-forming suspensions were dried at $120{ }^{\circ} \mathrm{C}$ for $60 \mathrm{~min}$ in a laboratory dryer SUP65W/G (WAMED Wytwórnia Aparatury Medycznej S.S.P, Warsaw, Poland). Then, the pre-dried films were moved to a ventilated chamber KBF 720 Binder (Tuttlingen, Germany) and dried at $25{ }^{\circ} \mathrm{C}$ and $50 \%$ relative humidity (RH) for $48 \mathrm{~h}$. Subsequently, the films were peeled off and conditioned again at $50 \% \mathrm{RH}$ and $25^{\circ} \mathrm{C}$ for $48 \mathrm{~h}$ prior to testing.

\section{Thickness}

Film thickness was measured with an electronic gauge Ultrametr A400 (Metrison Sp. z o.o., Mościska, Poland) having a precision of $1 \mu \mathrm{m}$. Film thickness was measured at ten random positions and expressed as mean value \pm standard deviation [17].

\section{Moisture content}

The moisture content (MC) of the film was determined by drying in a laboratory dryer SUP65W/G (WAMED Wytwórnia Aparatury Medycznej S.S.P, Warsaw, Poland) at $105 \pm 1{ }^{\circ} \mathrm{C}$ for $24 \mathrm{~h}$. Small test specimens were cut and placed into glass weighing bottles, and their weights were recorded before $(1 \pm 0.0001 \mathrm{~g})$ and after oven-drying. MC was calculated as the percentage of weight loss based on the original weight, using the following equation [27]:

$$
\% \mathrm{MC}=\frac{M_{i}-M_{d}}{M_{i}-M_{p}} \cdot 100
$$

where $M_{i}$ the weight of the glass weighing bottle and film specimen before drying (g), $M_{p}$ the weight of the glass weighing bottle $(\mathrm{g})$ and $M_{d}$ the weight of the glass weighing bottle and film specimen after drying $(\mathrm{g})$.

Three repetitive analyses of each film were made, and the results were expressed as mean value \pm standard deviation. 


\section{Colour}

Colour analysis of the films (air surface) was made with the use of Minolta CR-A70 (Konica Minolta Co., Ltd, Tokyo, Japan). The results were presented using directly measured parameters: $L^{*}$ (darkness/lightness), $a^{*}$ (green/red) and $b^{*}$ (blue/yellow). The measurements were made in 10 repetitions for every film. The mean values were reported. Colour of the films was expressed as the total colour difference $(\Delta E)$ according to the following equation [17]:

$$
\Delta E=\sqrt{\left(\Delta L^{*}\right)^{2}+\left(\Delta a^{*}\right)^{2}+\left(\Delta b^{*}\right)^{2}}
$$

where $\Delta E$ total colour difference (-); $\Delta L^{*}, \Delta a^{*}, \Delta b^{*}$ the differentials between the sample colour parameter and the colour parameter of a standard used as the film background (-).

\section{Opacity}

The opacity index of the films was calculated at ten repetitions by dividing the value of absorbance at $600 \mathrm{~nm}$ by film thickness according to the following formulas [28]:

$$
O=\frac{A_{600}}{\bar{\delta}}
$$

where $O$ opacity index $\left(1 \mathrm{~mm}^{-1}\right), A_{600}$ absorbance at $600 \mathrm{~nm}(-)$ and $\bar{\delta}$ average thickness of the sample $(\mathrm{mm})$.

The absorbance was measured using a UV/Vis Helios spectrophotometer test cell (Thermo Electron Corporation, Waltham, USA) with an empty test cell as the reference.

\section{Differential scanning calorimetry}

The edible films were studied by DSC TA Instrument Q200 differential scanning calorimeter (TA Instruments, New Castle, USA). The DSC technique was used to obtain heat flow $\left(\mathrm{W} \mathrm{g}^{-1}\right)$ versus temperature curves. The cell was purged with $50 \mathrm{~mL} \cdot \mathrm{min}^{-1}$ dry nitrogen and calibrated for baseline on an empty oven and for temperature using standard pure indium. Specific heat capacity $\left(C_{p}\right)$ was calibrated using a sapphire. The samples were cooled by a mechanical refrigerated cooling system. The edible films (7-8 mg) were hermetically sealed in aluminium pans (volume $30 \mu \mathrm{L}$ ). An empty hermetically sealed aluminium pan was used as a reference in each test. Samples were heated from -60 to $300{ }^{\circ} \mathrm{C}$ with heating rate $10{ }^{\circ} \mathrm{C} \min ^{-1}$. All analyses were completed in triplicate $[29,30]$. 


\section{Glass transition temperature $\left(T_{g}\right)$}

Modulated differential scanning calorimetry (MDSC) was used to determine the glass transition temperature of edible films. The thermal transition experiments in complexes were conducted with a differential scanning calorimeter DSC Q200 (TA Instruments, New Castle, USA). The cell was purged with $50 \mathrm{~mL} \cdot \mathrm{min}^{-1}$ dry nitrogen and calibrated by using standard pure indium. An empty hermetical sealed aluminium pan was used as a reference. The samples (7-8 mg) were hermetically sealed in aluminium pans and cooled from room temperature to $-90{ }^{\circ} \mathrm{C}$ at $5{ }^{\circ} \mathrm{C}$ per min and equilibrated for $5 \mathrm{~min}$. In the analysis of MDSC, samples were scanned from -90 to $200{ }^{\circ} \mathrm{C}$ at a constant heating rate of $2{ }^{\circ} \mathrm{C}$ per min with an amplitude of $1{ }^{\circ} \mathrm{C}$ and $60 \mathrm{~s}$ period of modulation. Diagrams were analysed with respect to the total, reversible and non-reversible heat flow. Glass transition temperature $\left(T_{\mathrm{g}}\right)$ was determined as the mid-point of a vertical shift in the reversing transition curve. All analyses were completed in triplicate [29].

\section{Microstructure}

The surface and cross-sectional morphology of the films was examined using scanning electron microscopy TM-3000 HITACHI (Hitachi High-Technologies Corporation, Chiyoda, Tokyo, Japan). Samples were coated with gold under vacuum. A $5 \mathrm{~mm} \times 5 \mathrm{~mm}$ film was fixed on the support using silver paste. The examination used an accelerating voltage of $15 \mathrm{kV}$, and the magnification was $500 \times$ for surface of the films and $500 \times$ for cross section of the films.

\section{Statistical analysis}

The statistical software Statistica 13.3 (StatSoft Inc., Tulsa, USA) and Excel 2010 (Microsoft, Redmond, Washington, USA) were used for data analysis. The analysis of variance (ANOVA) at a significance level of $95 \%$ was performed with post hoc Tukey's test to detect significant differences in film properties. If Shapiro-Wilk test for normality and Levene's test for homoscedasticity of data resulted in statistically significant $(p<0.05)$, nonparametric multiple range test Kruskal-Wallis was used, with a significant level of $95 \%(p<0.05)$.

\section{Results and discussion}

\section{The general characteristic of the edible films}

After blending, all the compounds and vacuum degassing the film-forming solutions were homogenous and smooth with no separation symptoms. All the researched films were flexible and easy to peel off and handle, without pores or cracks. Pure sodium alginate film was transparent, and sodium alginate-apple puree one was 
yellowish. The addition of vegetable oils resulted in a milky and opaque appearance of the films based on sodium alginate and apple puree. No visible losses of lipids after the removal of the films from the plates were observed. The appearance of both sides of the films was different, except for the sodium alginate film. For the sodium alginate-apple puree film matt upper surface with protrusions (small particles of apple puree) and slick, shiny lower surface was observed. The films incorporated with vegetable oils were silky to the touch with shiny upper and lower surface and protrusions (Fig. 1).

Thickness, moisture content, colour parameters and opacity are shown in Table 2. To form stand-alone structures edible films should have the proper thickness (usually up to $0.25 \mathrm{~mm}$ ) [31, 32]. The film thickness results showed some significant differences among treatments. Pure sodium alginate edible films had the highest thickness, while the incorporation of apple puree resulted in the lowest values of thickness. The addition of vegetable oils caused a slight increase in the values of thickness compared to sodium alginate-apple puree films. These results indicated that the addition of apple puree and vegetable oils altered the thickness and microstructure of the films. However, this was not later confirmed by microscopic analysis and may be explained by a very non-uniform structure of the films caused by the presence of thickened areas in the matrix as well as large particles of apple puree.

The moisture content of the researched films ranged from $15.49 \pm 0.18$ to $19.18 \pm 1.21 \%$ for the films with coconut oil and rapeseed oil, respectively. Nonetheless, only the values of moisture content for sodium alginate-apple puree edible films with coconut oil differed significantly in comparison with the rest of the samples.

General appearance and consumer acceptance are greatly influenced by the colour of food packaging [33]. For the developed edible films, the colour was closely related to the colorimetric parameters of apple puree, while the addition of vegetable oils was responsible for their milky appearance. The colour parameter $L^{*}$ provides a measure of lightness. The value of this parameter ranges from 0 to 100 (dark-light). A positive $a^{*}$ value is a measure of redness, and a negative value of greenness, while a positive $b^{*}$ value is a measure of yellowness, and a negative value of blueness [19]. Not only colour but also film transparency is an important factor influencing the overall appearance and quality of edible packaging. Lower film opacity was considered to be a desirable feature for food packaging films and coatings due to the fact that consumers prefer to see the foods inside a package [34]. Surface colour and opacity of the films were greatly influenced by blending with apple puree and vegetable oils as shown in Table 2 . The pure sodium alginate film was clear and transparent with a high lightness value of $93.69 \pm 0.58$. In general with the addition of apple puree, there were insignificant changes in $L^{*}$ and $a^{*}$ values. The addition of apple puree caused only statistically significant increase in the value of $b^{*}$ (the films were more yellow). Vegetable oils were in charge of the significant changes in the values of all colorimetric parameters causing a decrease in the lightness $L^{*}$ and greenness $a^{*}$ and increase in yellowness $b^{*}$, indicating the selected vegetable oils had significant influence on producing opaque milky films. The hazelnut oil appeared to have the biggest influence on the lightness, while coconut oil on the values of $a^{*}$ and $b^{*}$ resulting in yellowish and greenish films. The addition of fruit puree as 


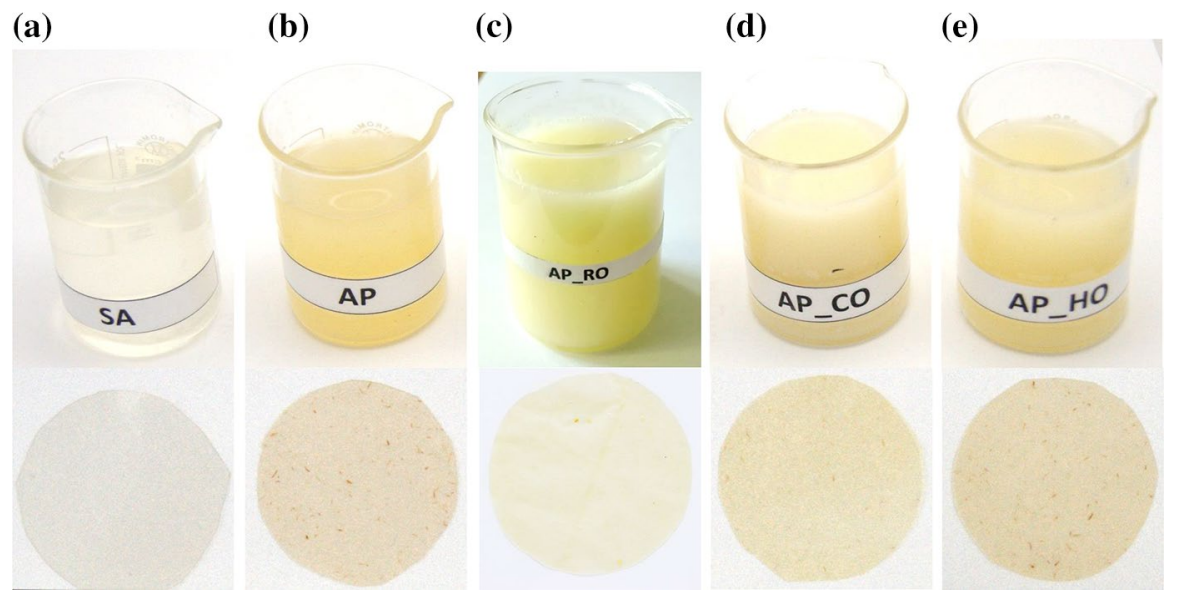

Fig. 1 Visual appearance of the film-forming solutions (upper row) and the films (lower row) a sodium alginate edible film, b sodium alginate-apple puree film and sodium alginate-apple puree films with different vegetable oils: $\mathbf{c}$ rapeseed oil, $\mathbf{d}$ coconut oil, $\mathbf{e}$ hazelnut oil

well as vegetable oils caused a statistically significant increase in the values of opacity, which was compatible with visual observations. Consequently, the total colour difference $(\Delta E)$ of the films with apple puree as well as with apple puree and the selected vegetable oils increased significantly compared with the pure sodium alginate film. Orsuwan et al. [35] explained the increase in the values of $b^{*}$ agar-banana powder blend films by the presence of the phenolic and terpenoids ( $\beta$-carotene) compounds in the banana powder. Similar observations related to the effect on vegetable oils of colorimetric parameters of edible films based on whey protein, were reported by Galus and Kadzińska [36, 37] while rapeseed oil, almond oil and walnut oil incorporation. All the obtained films were characterized by a decrease in the value of lightness $L^{*}$ in comparison with the control sample without vegetable oils. Nonetheless, equivocal changes in the values of $a^{*}$ and $b^{*}$ were observed when nut oils were added. In general, the films showed positive values of parameter $a^{*}$ (up to $0.98 \pm 0.05$ ) and negative values of parameter $b^{*}$ (up to $-0.79 \pm 0.08$ ). More consistent with the results obtained in this research were the results for whey protein isolate film with rapeseed oil resulting in more yellowish appearance. Moreover, the emulsified films were much more opaque than control whey films. Pereda et al. [38] explained this phenomenon by the fact that droplets dispersed in the matrix affect the transparency by preventing light transmission through the film.

\section{The thermal properties of the edible films}

DSC and MDSC analyses were carried out to investigate the influence of crosslinking induced by sodium alginate and also biopolymers present in apple puree on the thermal stability of sodium alginate-apple puree films. Tulamandi et al. [34] reported that the variation in the glass transition temperature $\left(T_{\mathrm{g}}\right)$, melting temperature $\left(T_{\mathrm{m}}\right)$ and enthalpy $(\Delta H)$ is best effective indicators of the 


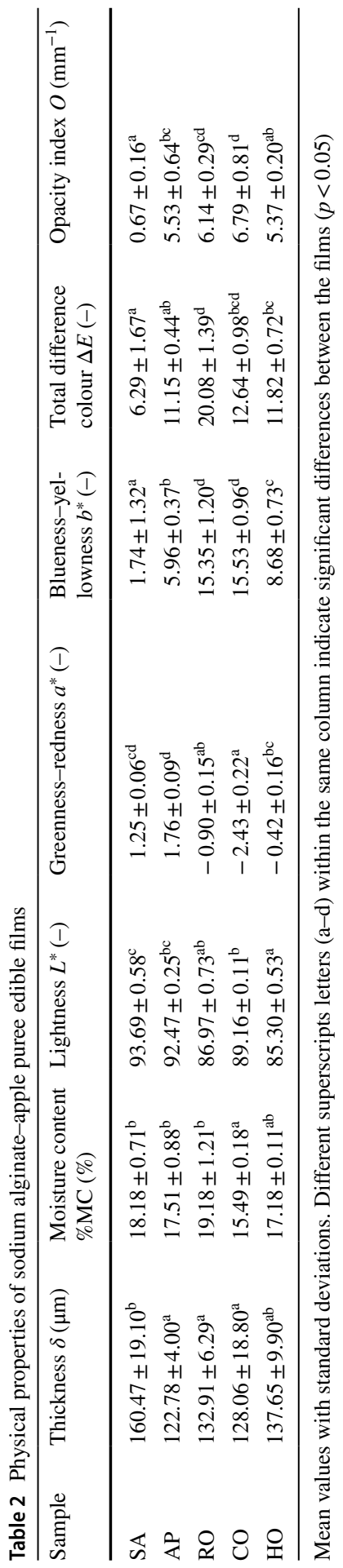


compatibility of different biopolymers. DSC and MDSC thermal characterization of pure sodium alginate, sodium alginate-apple puree as well as sodium alginate-apple puree-vegetable oil edible films are summarized in Table 3. Between one and three endothermic peaks could be observed in the traces for all the analysed samples depending on the film formulation (Fig. 2). In the DSC curves of edible films with vegetable oils, the first endothermic peak was responsible for the phenomenon of fat melting and ranged from $-15.79 \pm 0.76$ to $23.37 \pm 0.01{ }^{\circ} \mathrm{C}$ for rapeseed oil and coconut oil, respectively. The obtained values are in correspondence with the results obtained by Teles dos Santos et al. for rapeseed oil [39], Srivastava et al. [40] for coconut oil and by Tan and Che Man [41] for hazelnut oil. It testifies that differential scanning calorimetry is a method that enables identifying the kind of oil used while film preparation. Pure sodium alginate edible film was characterized by a DSC curve with two peaks, one endothermic at the temperature of $134.39 \pm 2.64{ }^{\circ} \mathrm{C}$ and the second one exothermic at $211.94 \pm 1.42{ }^{\circ} \mathrm{C}$ responsible for such phase transitions as melting and then sample decomposition. No exothermic peaks were observed in DSC curves for the films with apple puree which may proclaim that biopolymers present in fruit puree have a protective influence on the sample counteracting its decomposition and proving its high compatibility with sodium alginate to form well-blended films. Similar observations were reported by Orsuwan et al. [35] for agar-banana powder edible films. The authors indicated that all the blend films showed only one peak without any phase separation. The two endothermic peaks at the temperature over $100{ }^{\circ} \mathrm{C}$ observed for the films with apple puree as well as with and without vegetable oils are related to the phenomenon of various carbohydrates decomposition, e.g. monosaccharides such as glucose and fructose as well as pectins. Iijima et al. [42] observed a melting endothermic peak for pure pectin at the temperature of $154{ }^{\circ} \mathrm{C}$, while Athmaselvi et al. [43] presented DSC curves for guava powder in which they observed endothermic peaks centred at $208.66{ }^{\circ} \mathrm{C}$, $341.16^{\circ} \mathrm{C}$ and $500.75^{\circ} \mathrm{C}$, involving melting of pectin contained in guava, and a possible demethoxylation, dehydroxylation and decarboxylation of pectin and other polysaccharides. The values of melting temperature of the films obtained in this research may be also related to the melting of sugars such as glucose, fructose and saccharose which are present in high amount in apple puree. The obtained values of melting temperature are compatible with those for analytical grade crystalline sugars researched by Saavedra-Leos [44] who also reported the

Table 3 DSC and MDSC characterization of sodium alginate-apple puree edible films

\begin{tabular}{|c|c|c|c|c|c|c|}
\hline \multirow[t]{2}{*}{ Sample } & \multicolumn{3}{|c|}{ Glass transition temperature } & \multicolumn{3}{|c|}{ Melting temperature } \\
\hline & $T_{\mathrm{g} \text { onset }}\left({ }^{\circ} \mathrm{C}\right)$ & $T_{\mathrm{g} \text { mid-point }}\left({ }^{\circ} \mathrm{C}\right)$ & $T_{\mathrm{g} \text { endpoint }}\left({ }^{\circ} \mathrm{C}\right)$ & $T_{\mathrm{m} 1}\left({ }^{\circ} \mathrm{C}\right)$ & $T_{\mathrm{m} 2}\left({ }^{\circ} \mathrm{C}\right)$ & $T_{\mathrm{m} 3}\left({ }^{\circ} \mathrm{C}\right)$ \\
\hline SA & $-23.60 \pm 2.43$ & $-21.96 \pm 2.35$ & $-20.37 \pm 2.33$ & $134.39 \pm 2.64$ & $211.94 \pm 1.42$ & - \\
\hline AP & $-43.51 \pm 3.02$ & $-35.35 \pm 1.11$ & $-27.18 \pm 0.80$ & $156.86 \pm 0.60$ & $183.04 \pm 1.89$ & - \\
\hline RO & $-31.50 \pm 7.58$ & $-27.59 \pm 5.32$ & $-22.08 \pm 0.82$ & $-15.79 \pm 0.76$ & $148.91 \pm 8.89$ & - \\
\hline $\mathrm{CO}$ & $-42.65 \pm 1.92$ & $-33.19 \pm 0.97$ & $-23.91 \pm 0.21$ & $23.37 \pm 0.01$ & $152.67 \pm 0.69$ & $177.50 \pm 0.83$ \\
\hline $\mathrm{HO}$ & $-43.97 \pm 0.37$ & $-38.13 \pm 0.37$ & $-32.25 \pm 0.39$ & $-6.94 \pm 0.13$ & $120.69 \pm 22.20$ & $148.88 \pm 17.59$ \\
\hline
\end{tabular}



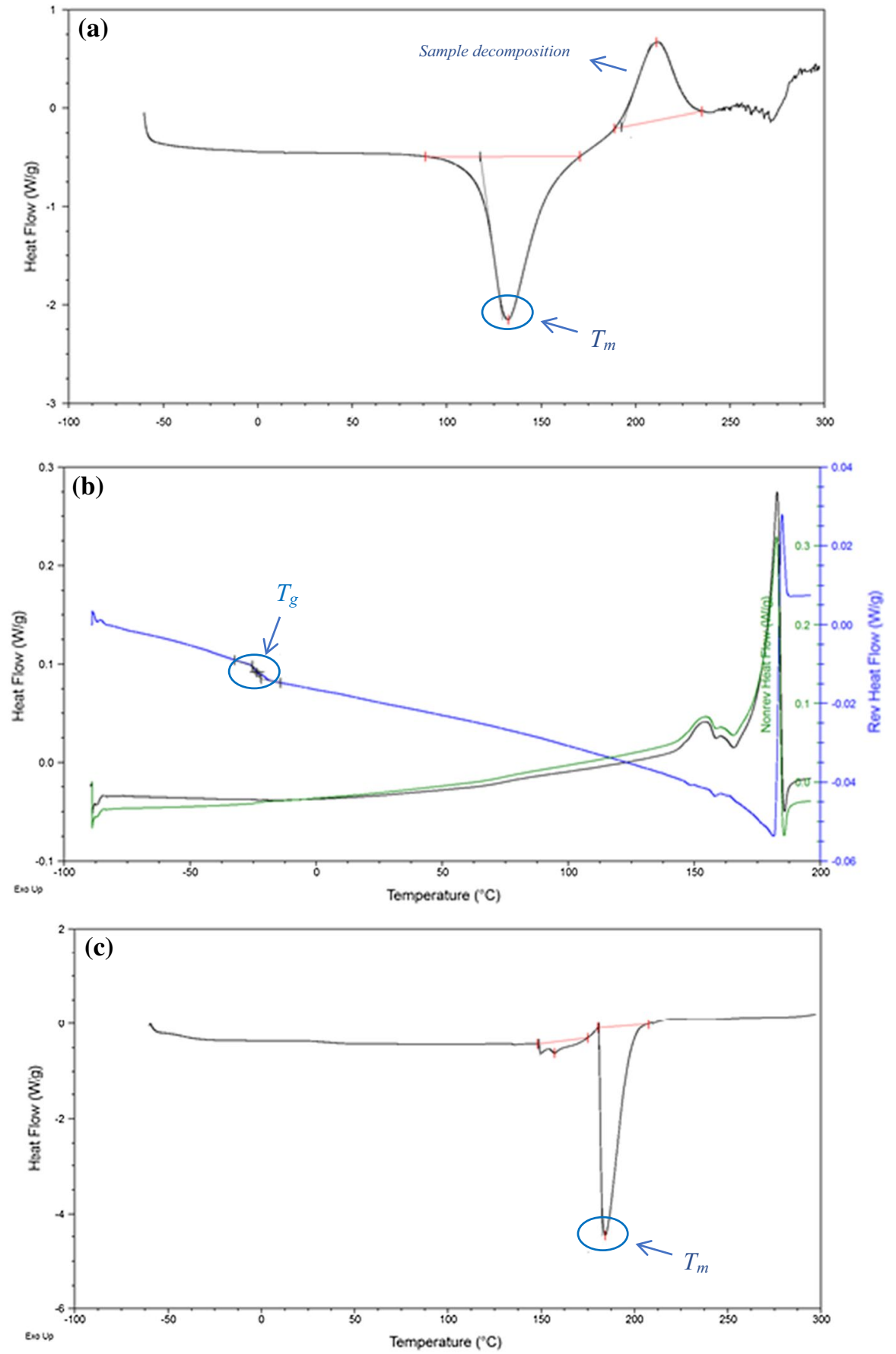

Fig. 2 Examples of thermograms for the studied films: a (DSC), b (MDSC)—pure sodium alginate edible film; c (DSC), d (MDSC)—sodium alginate-apple puree edible film; e (DSC), f (MDSC)—sodium alginate-apple puree edible film with oil 

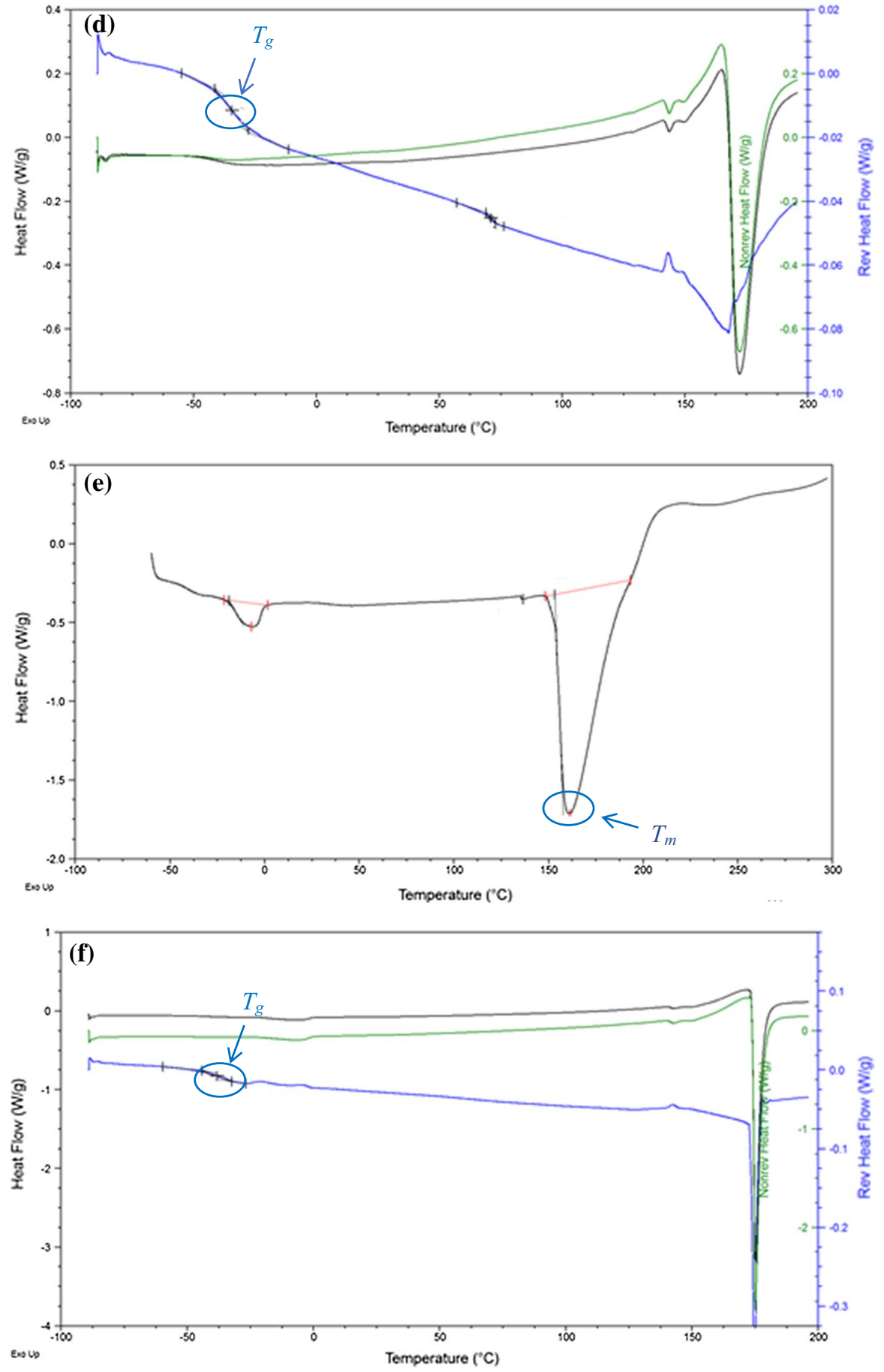

Fig. 2 (continued) 
values of degradation temperature between 195 and $235^{\circ} \mathrm{C}$ for fructose and saccharose, respectively. The authors of this research did not observe any peaks at these values of temperature and suspected a protective impact of the natural blend of various carbohydrates and proteins present in apple puree on the thermal stability of edible films. MDSC analysis enabled finding the values of glass transition temperature $\left(T_{\mathrm{g}}\right)$ which were very low and ranged from about -22 to about $-39{ }^{\circ} \mathrm{C}$, and this implies that these materials are not in the glassy state at room temperature $\left(\sim 25^{\circ} \mathrm{C}\right)$, the temperature used in the second step of drying, in conditioning as well as in all the characterization. According to Chang et al. [45], plasticization weakens the intermolecular forces between polymer chains and, consequently, diminishes the overall cohesion, reducing $T_{\mathrm{g}}$. The lower values of glass transition temperature are related to the presence of natural plasticizers with low molecular weight in apple puree such as fructose, glucose and saccharose as well as to the plastifying activity of vegetable oils. So low values of $T_{\mathrm{g}}$ were also caused by the presence of water. (The values of water activity of the researched films fluctuated around 0.5.) The phenomenon with only one $T_{\mathrm{g}}$, observed in blended polymers in a DSC scan, indicated good compatibility of the component biopolymers with pure, chemically isolated from raw materials, sodium alginate [34].

\section{The microstructure of the edible films}

Microscopy images allow understanding the differences in the film morphology due to the addition of the apple puree as well as the vegetable oils. Sodium alginate film had a homogenous solid structure, which could be compared to concrete (Fig. 3a). Control film based on sodium alginate and apple puree had a more heterogeneous surface with structures that protruded from the air-side surface of the film and some internal pores. The protrusions were more evident in the cross section of the film. They appeared to be large dense portions of the film, probably a result of differential surface tension while drying, but also big particles of apple puree.

Similar to our results, Espitia et al. [19] analysed pectin films with açaí puree and revealed the differences between pure pectin film and the one with the addition of fruit puree. They proved that formation of the thickened areas was an effect of acai rather than pectin. Also Martelli et al. [46] observed randomly distributed pores inside the matrix of pectin-banana puree edible films. A rough surface is a characteristic element of these films and is indicated by the authors as an evidence of their plastic behaviour.

Sodium alginate-apple puree edible films incorporated with all the vegetable oils had a heterogeneous surface with visible oil droplets randomly distributed in the matrix, with a tendency to cluster formation. The cross section of the films revealed that the oil droplets were closed in the internal pores of the polymer matrix and were present in its various layers, whereby the most uniform distribution was observed for edible films with coconut oil, which is supposed to be the result of its solid nature at ambient temperature and less tendency to migrate while drying. 
(a)

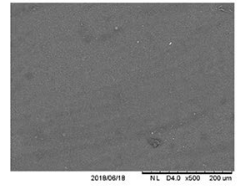

(b)
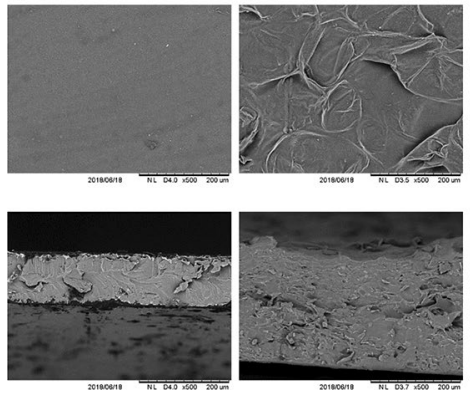

(c)
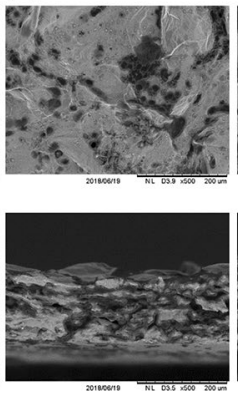

(d)

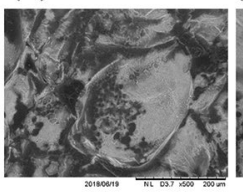

(e)

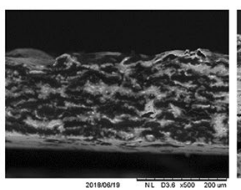

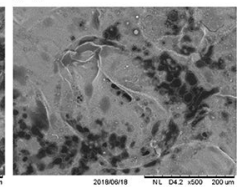

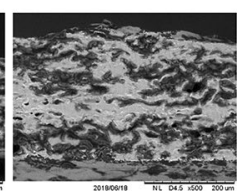

Fig. 3 Scanning electron micrographs of the surface (magnification $\times 500$, upper row) and cross sections (magnification $\times 500$, bottom row) of a sodium alginate edible film, $\mathbf{b}$ sodium alginate-apple puree film and sodium alginate-apple puree films with different vegetable oils: c rapeseed oil, $\mathbf{d}$ coconut oil, $\mathbf{e}$ hazelnut oil

For sodium alginate-apple puree edible films with hazelnut oil, two regions of oil droplets distribution could be observed-close to air-side surface and to plate-side surface, whereas rapeseed oil droplets were randomly distributed inside the matrix.

The similar observations have been previously reported by Murillo-Martínez et al. [47] who designed water-in-oil-in-water double emulsions stabilized with lowmethoxyl pectin and whey protein isolate or sodium carboxymethylcellulose and whey protein isolate to produce edible films. Although there were the same main structural features for the CMC-WPI and LMP-WPI films, the differences in the size and spatial distribution of emulsion droplets were observed. On the other hand, the issue of oil droplets distribution inside the polymer matrix seems to be insignificant in comparison with the whey protein isolate edible films incorporated with almond and walnut oils researched by Galus and Kadzińska [36]. The authors observed that the emulsion films had heterogeneous and rough surface with discontinuities caused by the formation of two phases (protein and lipid) in the matrix. Such a phenomenon testifies to the lack of integrity between the molecules of hydrophilic and hydrophobic features and was confirmed by Pereda et al. [38] as well as Valenzuela et al. [48] for chitosan-olive oil and quinoa protein-chitosan-sunflower oil films, respectively. The solution to this problem was proposed by Orsuwan and Sothornvit [21] and Daudt et al. [24] who suggested developing edible films from the natural compatible mixtures of polysaccharides, proteins and lipids such as flours instead of artificially prepared blends of pure, priorly isolated from raw materials, compounds.

\section{Conclusions}

The combination of sodium alginate, apple puree and vegetable oils such as rapeseed oil, coconut oil and hazelnut oil resulted in visually attractive, flexible, thermodynamically compatible edible films. All the films had the thickness and moisture content characteristic for this type of materials. The results showed that the addition of apple puree and vegetable oils had a significant effect on the visual appearance 
of edible films causing a decrease in lightness and an increase in greenness (except for apple puree) and yellowness. The films were also more opaque in comparison with pure sodium alginate films. DSC curves showed between one and three endothermic peaks responsible for melting of various compounds in film formulations as well as one exothermic peak in the curves for pure sodium alginate testifying for its decomposition. There were no exothermic peaks observed for blended films which proved protective influence of apple puree as well as compatibility between particular compounds of edible films. $T_{\mathrm{g}}$ values were affected by the presence of water and sugars with low molecular weight. The drying conditions used for film production and the formulations appeared to be suitable to provide thermodynamic compatibility of particular compounds and thus to avoid phase separation. According to the authors, a promising starting point is an in-depth analysis of the chemical composition of fruit and vegetable semi-products used as a component of the solutions forming the matrix. Further study of the properties of the film obtained from natural blends and their comparison with the properties of films produced from the component of the same botanical source would provide important information about the nature of interactions within the polymer matrix. A better understanding of the nature of edible films, sheets and coatings based on semi-finished fruit and vegetable products is a promising direction of research, which fits perfectly into the policy of sustainable development.

Open Access This article is distributed under the terms of the Creative Commons Attribution 4.0 International License (http://creativecommons.org/licenses/by/4.0/), which permits unrestricted use, distribution, and reproduction in any medium, provided you give appropriate credit to the original author(s) and the source, provide a link to the Creative Commons license, and indicate if changes were made.

\section{References}

1. GREX_Groupe de trevail Previsions Pommes, FWG-Forecast Working Group for Apples (2018) The apple market in the EU: production, prices and trade [Internet]. https://ec.europa.eu/agricultur e/sites/agriculture/files/fruit-and-vegetables/product-reports/apples-and-pears/expert-group/apple s-2018-05_fr.pdf. Cited 27 Aug 2018

2. Torres CA, Romero LA, Diaz RI (2015) Quality and sensory attributes of apple and quince leathers made without preservatives and with enhanced antioxidant activity. LWT Food Sci Technol 62(2):996-1003. https://doi.org/10.1016/j.lwt.2015.01.056

3. Du WX, Avena-Bustillos RJ, Woods R, Breksa AP, McHugh TH, Friedman M, Levin CE, Mandrell $R$ (2012) Sensory evaluation of baked chicken wrapped with antimicrobial apple and tomato edible films formulated with cinnamaldehyde and carvacrol. J Agric Food Chem 60(32):7799-7804

4. Offia-Olua BI, Ekwunife OA (2015) Production and evaluation of the physico-chemical and sensory qualities of mixed fruit leather and cakes produced from apple (Musa pumila), banana (Musa sapientum), pineapple (Ananas comosus). Niger Food J 33(1):22-28

5. Cichowska J, Samborska K, Kowalska H (2018) Influence of chokeberry juice concentrate used as osmotic solution on the quality of differently dried apples during storage. Eur Food Res Technol 244(10):1773-1782. https://doi.org/10.1007/s00217-018-3089-1

6. Erkmen O, Barazi AO (2018) General characteristics of edible films. J Food Biotechnol Res 2(13): $1-4$

7. Otoni CG, Avena-Bustillos RJ, Azeredo HMC, Lorevice MV, Moura MR, Mattoso LHC, McHugh TH (2017) Recent advances on edible films based on fruits and vegetables-a review. Compr Rev Food Sci Food Saf 16(5):1151-1169 
8. Valenzuela C, Tapia C, López L, Bunger A, Escalona V, Abugoch L (2015) Effect of edible quinoa protein-chitosan based films on refrigerated strawberry (Fragaria $\times$ ananassa) quality. Electron $\mathrm{J}$ Biotechnol 18(6):406-411. https://doi.org/10.1016/j.ejbt.2015.09.001

9. Wang X, Kong D, Ma Z, Zhao R (2015) Effect of carrot puree edible films on quality preservation of fresh-cut carrots. Irish J Agric Food Res 1:64-71

10. Oussalah M, Caillet S, Salmiéri S, Saucier L, Lacroix M (2004) Antimicrobial and antioxidant effects of milk protein-based film containing essential oils for the preservation of whole beef muscle. J Agric Food Chem 52(18):5598-5605

11. Antoniou J, Liu F, Majeed H, Zhong F (2015) Characterization of tara gum edible films incorporated with bulk chitosan and chitosan nanoparticles: a comparative study. Food Hydrocoll 44:309319. https://doi.org/10.1016/j.foodhyd.2014.09.023

12. Orsuwan A, Shankar S, Wang LF, Sothornvit R, Rhim JW (2017) One-step preparation of banana powder/silver nanoparticles composite films. J Food Sci Technol 54(2):497-506

13. Azeredo HMC, Mattoso LHC, Wood D, Williams TG, Avena-Bustillos RJ, McHugh TH (2009) Nanocomposite edible films from mango puree reinforced with cellulose nanofibers. J Food Sci 74(5):31-35

14. Chambi H, Grosso C (2006) Edible films produced with gelatin and casein cross-linked with transglutaminase. Food Res Int 39(4):458-466

15. Pavli F, Tassou C, Nychas GJE, Chorianopoulos N (2018) Probiotic incorporation in edible films and coatings: bioactive solution for functional foods. Int J Mol Sci. https://doi.org/10.3390/ijms1 9010150

16. Il PS, Zhao Y (2006) Development and characterization of edible films from cranberry pomace extracts. J Food Sci 71(2):E95-E101

17. Sothornvit R, Pitak N (2007) Oxygen permeability and mechanical properties of banana films. Food Res Int 40(3):365-370

18. Ranjitha K, Sudhakar Rao DV, Shivashankara KS, Oberoi HS, Roy TK, Bharathamma H (2017) Shelf-life extension and quality retention in fresh-cut carrots coated with pectin. Innov Food Sci Emerg Technol 42(May):91-100. https://doi.org/10.1016/j.ifset.2017.05.013

19. Espitia PJP, Avena-Bustillos RJ, Du WX, Teófilo RF, Soares NFF, McHugh TH (2014) Optimal antimicrobial formulation and physical-mechanical properties of edible films based on açaí and pectin for food preservation. Food Packag Shelf Life 2(1):38-49

20. NewGem FoodsTM (2018) NewGem products [Internet]. http://www.newgemfoods.com/products. Cited 2 June 2018

21. Orsuwan A, Sothornvit R (2017) Effect of banana and plasticizer types on mechanical, water barrier, and heat sealability of plasticized banana-based films. J Food Process Preserv. https://doi. org/10.1111/jfpp.13380

22. Galus S, Kadzińska J (2016) Moisture sensitivity, optical, mechanical and structural properties of whey protein-based edible films incorporated with rapeseed oil. Food Technol Biotechnol 54(1):78-89

23. Pelissari FM, Andrade-Mahecha MM, do Sobral PJ, Menegalli FC (2013) Optimization of process conditions for the production of films based on the flour from plantain bananas (Musa paradisiaca). LWT Food Sci Technol 52(1):1-11. https://doi.org/10.1016/j.1wt.2013.01.011

24. Daudt RM, Avena-Bustillos RJ, Williams T, Wood DF, Külkamp-Guerreiro IC, Marczak LDF, McHugh TH (2016) Comparative study on properties of edible films based on pinhão (Araucaria angustifolia) starch and flour. Food Hydrocoll 60:279-287. https://doi.org/10.1016/j.foodh yd.2016.03.040

25. Dias AB, Müller CMO, Larotonda FDS, Laurindo JB (2010) Biodegradable films based on rice starch and rice flour. J Cereal Sci 51(2):213-219

26. Andrade-Mahecha MM, Tapia-Blácido DR, Menegalli FC (2012) Development and optimization of biodegradable films based on achira flour. Carbohydr Polym 88(2):449-458. https://doi. org/10.1016/j.carbpol.2011.12.024

27. Zahedi Y, Ghanbarzadeh B, Sedaghat N (2010) Physical properties of edible emulsified films based on pistachio globulin protein and fatty acids. J Food Eng 100(1):102-108

28. Gómez-Estaca J, Giménez B, Montero P, Gómez-Guillén MC (2009) Incorporation of antioxidant borage extract into edible films based on sole skin gelatin or a commercial fish gelatin. J Food Eng 92(1):78-85. https://doi.org/10.1016/j.jfoodeng.2008.10.024

29. Górska A, Ostrowska-Ligęza E, Szulc K, Wirkowska M (2012) A differential scanning calorimetric study of $\beta$-lactoglobulin and vitamin D3 complexes. J Therm Anal Calorim 110(1):473-477 
30. Ostrowska-Ligeza E, Górska A, Wirkowska M, Koczoń P (2012) An assessment of various powdered baby formulas by conventional methods (DSC) or FT-IR spectroscopy. J Therm Anal Calorim 110(1):465-471

31. Han JH, Gennadios A (2005) Innovations in food packaging. In: Han JH (eds) Innovations in food packaging. Elsevier, Amsterdam, pp 239-262. http://www.sciencedirect.com/science/article/pii/ B9780123116321500462

32. Skurtys O, Acevedo C, Pedreschi F, Enrione J, Osorio F, Aguilera JM (2010) Food hydrocolloid edible films and coatings. In: Hollingworth CS (ed) Food hydrocolloids; characteristics, properties and structures. Nova Science Publishers Inc., New York, pp 41-80

33. Espitia PJP, Avena-Bustillos RJ, Du WX, Sen CB, Williams TG, Wood D, McHugh TH, Soares FF (2014) Physical and antibacterial properties of açaí edible films formulated with thyme essential oil and apple skin polyphenols. J Food Sci 79(5):M903-M910

34. Tulamandi S, Rangarajan V, Rizvi SSH, Singhal RS, Chattopadhyay SK, Saha NC (2016) A biodegradable and edible packaging film based on papaya puree, gelatin, and defatted soy protein. Food Packag Shelf 10:60-71. https://doi.org/10.1016/j.fps1.2016.10.007

35. Orsuwan A, Shankar S, Wang LF, Sothornvit R, Rhim JW (2016) Preparation of antimicrobial agar/ banana powder blend films reinforced with silver nanoparticles. Food Hydrocoll 60:476-485. https ://doi.org/10.1016/j.foodhyd.2016.04.017

36. Galus S, Kadzińska J (2016) Whey protein edible films modified with almond and walnut oils. Food Hydrocoll 52:78-86

37. Galus S, Kadzińska J (2015) Food applications of emulsion-based edible films and coatings. Trends Food Sci Technol 45(2):273-283

38. Pereda M, Amica G, Marcovich NE (2012) Development and characterization of edible chitosan/ olive oil emulsion films. Carbohydr Polym 87(2):1318-1325. https://doi.org/10.1016/j.carbp ol.2011.09.019

39. Teles dos Santos M, Viana IS, Ract JNR, Le Roux GAC (2016) Thermal properties of palm stearin, canola oil and fully hydrogenated soybean oil blends: coupling experiments and modeling. J Food Eng 185:17-25. https://doi.org/10.1016/j.jfoodeng.2016.03.029

40. Srivastava Y, Semwal AD, Sajeevkumar VA, Sharma GK (2017) Melting, crystallization and storage stability of virgin coconut oil and its blends by differential scanning calorimetry (DSC) and Fourier transform infrared spectroscopy (FTIR). J Food Sci Technol 54(1):45-54

41. Tan CP, Man YCYB (2002) Comparative differential scanning calorimetric analysis of vegetable oils: I. Effects of heating rate variation. Phytochem Anal 13(3):129-141

42. Iijima M, Nakamura K, Hatakeyama T, Hatakeyama H (2000) Phase transition of pectin with sorbed water. Carbohydr Polym 41(1):101-106

43. Athmaselvi KA, Kumar C, Balasubramanian M, Roy I (2014) Thermal, structural, and physical properties of freeze dried tropical fruit powder. J Food Process 2014:1-10. https://doi. org/10.1155/2014/524705

44. Saavedra-Leos MZ, Alvarez-Salas C, Esneider-Alcalá MA, Toxqui-Terán A, Pérez-García SA, RuizCabrera MA (2012) Towards an improved calorimetric methodology for glass transition temperature determination in amorphous sugars. CYTA J Food 10(4):258-267. https://doi.org/10.1080/19476 337.2011.639960

45. Chang YP, Cheah PB, Seow CC (2000) Plasticizing-antiplasticizing effects of water on physical properties of tapioca starch films in the glassy state. J Food Sci 65(3):445-451. https://doi. org/10.1111/j.1365-2621.2000.tb16025.x

46. Martelli MR, Barros TT, De Moura MR, Mattoso LHC, Assis OBG (2013) Effect of chitosan nanoparticles and pectin content on mechanical properties and water vapor permeability of banana puree films. J Food Sci 78(1):N98-N104. https://doi.org/10.1111/j.1750-3841.2012.03006.x

47. Murillo-Martínez MM, Pedroza-Islas R, Lobato-Calleros C, Martínez-Ferez A, Vernon-Carter EJ (2011) Designing W1/O/W2 double emulsions stabilized by protein-polysaccharide complexes for producing edible films: rheological, mechanical and water vapour properties. Food Hydrocoll 25(4):577-585. https://doi.org/10.1016/j.foodhyd.2010.06.015

48. Valenzuela C, Abugoch L, Tapia C (2013) Quinoa protein-chitosan-sunflower oil edible film: mechanical, barrier and structural properties. LWT Food Sci Technol 50(2):531-537. https://doi. org/10.1016/j.lwt.2012.08.010 
Publisher's Note Springer Nature remains neutral with regard to jurisdictional claims in published maps and institutional affiliations. 